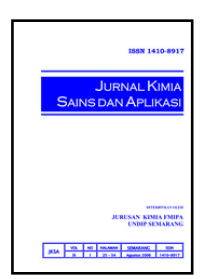

\title{
Kitosan sebagai Bahan Dasar Drug Delivery: Studi Interaksi Segmen Dimer Kitosan dengan Vitamin $C$ secara Komputasi Ab Initio dan Eksperimen
}

\author{
Sekar Kusuma Dewi ${ }^{\mathrm{a}}$, Tri Windarti ${ }^{\mathrm{a}}$, Parsaoran Siahaan ${ }^{\mathrm{a}}$ \\ a Physical Chenistry Laboratory, Chemistry Department, Faculty of Sciences and Mathematics, Diponegoro University, Jalan Prof. \\ Soedarto, Tembalang, Semarang \\ * Corresponding author: siahaan.parsaoran@live.undip.ac.id
}

\section{Article Info}

Keywords: computation, chitosan, ascorbate acid, interaction energy

\section{Abstract}

Studies of intermolecular interactions between chitosan and vitamin $\mathrm{C}$ are computed ab initio and experiments to understand the use of chitosan as a basic drug delivery has been done. The parameters analyzed were the energy of IR interactions and spectra. The calculations are made on two interaction conformations, ie between the $\mathrm{N}$-atom side segments of the partially negated partially charged chitosan dimer each with the $\mathrm{H}$ atom side on the positively charged partial positions of the vitamin $\mathrm{C}$ ring and the side of the $\mathrm{H}$ atom outside the ring (conformation II). The energy and interaction distance of configuration I were respectively $-62,263 \mathrm{~kJ} \mathrm{mol-1}$ and $1,897 \AA$, while the II configuration is $-32,641 \mathrm{~kJ} \mathrm{~mol}-1$ and $2,226 \AA$. The IR spectra show the vibration modes in the two interacting compounds. The conclusion of modeling results is that chitosan can bind vitamin $\mathrm{C}$ with different energy. The results of the modeling were verified by vitamin $\mathrm{C}$ absorption by chitosan by mixing $2.5 \mathrm{~g}$ of chitosan and $0.25 \%$ vitamin $\mathrm{C}$ solution. The remaining vitamin $\mathrm{C}$ measurements and slow release test of vitamin $\mathrm{C}$ absorbed in chitosan in aqueous media were performed with a UV-Vis spectrophotometer. Experimental results showed that chitosan absorbed vitamin $\mathrm{C}$ by $46.5 \%$ and in the first 10 minutes of vitamin $C$ concentration was released $95.15 \mathrm{ppm}$.

\section{Abstrak}

Studi interaksi antarmolekul antara kitosan dan vitamin C secara komputasi ab initio dan eksperimen untuk memahami penggunaan kitosan sebagai bahan dasar drug delivery telah dilakukan. Parameter yang dianalisis adalah energi interaksi dan spektra IR. Perhitungan dilakukan terhadap dua konformasi interaksi yaitu antara sisi atom $\mathrm{N}$ segmen dimer kitosan bermuatan parsial negatip masing-masing dengan sisi atom $\mathrm{H}$ pada cincin vitamin $\mathrm{C}$ yang bermuatan parsial positip (konformasi I) dan sisi atom $\mathrm{H}$ di luar cincin (konformasi II). Energi dan jarak interaksi konfigurasi I masing-masing sebesar -62,263 kJ mol-1 dan 1,897 $\AA$, sedangkan konfigurasi II sebesar -32,641 kJ mol1 dan 2,226 ̊. Spektra IR menunjukkan mode-mode vibrasi pada kedua senyawa yang berinteraksi. Kesimpulan hasil pemodelan adalah bahwa kitosan dapat mengikat vitamin $\mathrm{C}$ dengan energi yang berbeda. Hasil pemodelan diverifikasi dengan absorpsi vitamin C oleh kitosan melalui pencampurkan 2,5 g kitosan dan 0,25 \% larutan vitamin C. Pengukuran vitamin $\mathrm{C}$ yang tersisa dan uji lepas lambat vitamin $\mathrm{C}$ yang terserap dalam kitosan dalam media air dilakukan dengan spektrofotometer UV-Vis. Hasil eksperimen menunjukkan bahwa kitosan dapat menyerap vitamin C sebesar 46,5\% serta pada 10 menit pertama konsentrasi vitamin C yang dilepas sebesar 95,15 ppm. 


\section{Pendahuluan}

Kitosan, ß-1,4-poli-D-glukosamin, merupakan biopolimer yang didapatkan melalui proses deasetilasi basa kitin. Kitosan mempunyai sifat tidak larut dalam air, mudah terurai oleh bakteri, tidak beracun serta pada struktur kitosan terdapat banyak gugus aktif yang dapat berinteraksi dengan molekul lain, sehingga dapat diaplikasikan sebagai drug delivery [1, 2]. Aplikasi kitosan sebagai drug delivery yang telah dilakukan diantaranya sebagai drug delivery hormon insulin dan zat antikanker $[3,4]$.

Sifat kitosan sebagai drug delivery yang sangat penting dikaji adalah kemampuannya berinteraksi dengan molekul lain. Metode yang digunakan adalah komputasi $a b$ initio. Namun demikian, komputasi tidak mudah dilakukan untuk molekul sekompleks kitosan, sehingga didekati dengan model molekul sederhana segmen dimer kitosan. Vitamin $\mathrm{C}$ dipilih sebagai model zat yang berinteraksi dengan vitamin $\mathrm{C}$, karena disamping sederhana untuk perhitungan, juga mudah diukur dengan spektroskopi UV-Vis sebagai metode verifikasi interaksi antar kedua zat.

Penelitian mengenai pemanfaatan kitosan sebagai drug delivery vitamin $\mathrm{C}$ menunjukkan bahwa kitosan dapat digunakan untuk menyerap vitamin $\mathrm{C}$ dan vitamin C yang terserap dapat lepas secara bertahap jika dilarutkan dalam media air. Kemampuan kitosan untuk menyerap dan melepaskan vitamin $\mathrm{C}$ secara bertahap, diperkirakan berkaitan dengan energi interaksi antara kitosan dengan vitamin C. Besarnya energi interaksi antara kedua molekul tersebut sulit ditentukan secara eksperimen, namun dapat dilakukan dengan pemodelan komputasi ab initio. Hasil perhitungan terhadap molekul kitosan menunjukkan bahwa sisi atom $\mathrm{N}$ dimer kitosan adalah bermuatan parsial negatip, dan mampu berinteraksi kuat dengan kalsium fosfat melalui sisi muatan parsial positipnya. Muflikhah [5] juga telah menunjukkan sifat-sifat interaksi antara segmen dimer selulosa dengan kalsium fosfat. Kedua hasil tersebut menunjukkan bahwa sisi muatan parsial positip dan negatip yang dimiliki molekul sangat menentukan pada besarnya energi interaksi antarmolekul.

Oleh karena itu, pada penelitian ini akan dikaji pengaruh posisi sisi atom-atom yang berinteraksi antara segmen dimer kitosan dengan vitamin C (segmen dimer kitosan...vitamin C) terhadap energi interaksi yang dihasilkan, menggunakan software Gaussian03 dan basis set $6-31 \mathrm{G}(\mathrm{d}, \mathrm{p})$. Pada perhitungan komputasi, dilakukan optimasi geometri untuk segmen dimer kitosan dan molekul tunggal vitamin C sehingga didapatkan struktur geometri yang paling stabil. Struktur hasil optimasi dari masing-masing molekul, kemudian diinteraksikan. Energi interaksi antara segmen dimer kitosan...vitamin C yang dihasilkan, dipengaruhi oleh muatan dari atom-atom yang berinteraksi dan efek sterik. Semakin rendah nilai energi interaksi yang dihasilkan, maka interaksi akan semakin kuat sehingga molekul akan semakin stabil. Diperkirakan jika kitosan yang sudah mengandung vitamin C dilarutkan didalam media lain (air) maka energi interaksi yang lebih kecil akan lepas terlebih dahulu dan diikuti oleh energi interaksi yang lebih besar.

Hasil perhitungan komputasi, kemudian diuji kemampuan kitosan untuk menyerap dan melepas vitamin $\mathrm{C}$ dengan merendaman kitosan...vitamin $\mathrm{C}$ ke dalam media air dengan variasi waktu kontak. Konsentrasi vitamin C yang diserap dan dilepas oleh kitosan kemudian diuji dengan spektrofotometer UV-Vis dan analisis gugus fungsi menggunakan FTIR.

\section{Metode Penelitian}

\section{Alat dan Bahan}

Alat yang digunakan pada peneitian ini adalah seperangkat komputer dengan sistem operasi Windows XP SP 2, seperangkat alat gelas, neraca analitis (Mettler AT 200), hot plate, spektrofotometer UV-Vis (T-60 U Spectrophotometer), spektrofotometer FTIR (SHIMADZU), dan neraca analitik (Kern Als 220-4N). Bahan yang digunakan pada penelitian ini kitosan (CV. OceanFresh) dan vitamin C (Hebei Welcome Pharmaceutical Co).

\section{Perhitungan interaksi antar molekul}

Pada optimasi geometri molekul tunggal vitamin C, segmen dimer kitosan dan interaksi segmen dimer kitosan...vitamin C diperlukan data input yang dinyatakan dalam matriks-Z. Pada optimasi interaksi segmen dimer kitosan...vitamin C dilakukan variasi interaksi yakni antara atom $\mathrm{N}$ dari kitosan dengan atom $\mathrm{H}$ dari dalam dan luar cincin vitamin C. Energi interaksi antar molekul dapat dihitung dengan cara:

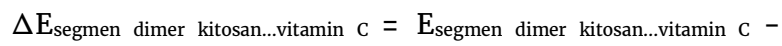
(Esegmen dimer kitosan + Evitamin C).

\section{Adsorpsi Vitamin C dalam Kitosan}

Adsorpsi vitamin C dilakukan dengan cara merendam 2,5 gram kitosan ke dalam vitamin C 0,25 \%. Perendaman ini dilakukan pada suhu kamar dan disertai pengadukan selama 120 menit.

\section{Uji Lepas Lambat Vitamin C}

Vitamin C yang sudah terserap oleh kitosan, kemudian dilakukan pengujian desorpsi. Desorpsi vitamin C dalam kitosan dilakukan dengan cara merendam kitosan vitamin $\mathrm{C}$ dalam $100 \mathrm{~mL}$ akuades yang disertai pengadukan dengan variasi waktu perendaman yakni 10; 20; 30; 40; 50; 1440 menit. Jumlah vitamin $\mathrm{C}$ yang dilepas oleh kitosan kemudian diuji dengan spektrofotometer UV-Vis.

\section{Hasil dan Pembahasan}

Molekul Tunggal Vitamin C

Hasil perhitungan diketahui bahwa pada struktur awal vitamin $C$ memiliki energi sebesar $-1,742.10^{6} \mathrm{~kJ}$ $\mathrm{mol}^{-1}$ dan setelah dilakukan penataan ulang atom-atom vitamin $\mathrm{C}$, didapatkan energi sebesar $-1,789.10^{6} \mathrm{~kJ} \mathrm{~mol}^{-}$ ${ }^{1}$. Energi hasil optimasi bernilai negatif yang menandakan bahwa struktur hasil optimasi geometri 
stabil. Struktur vitamin C sebelum dan sesudah optimasi dapat dilihat pada gambar 1 dan 2 .

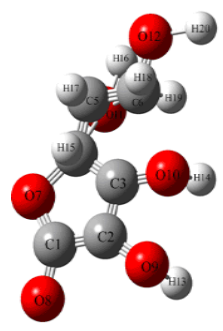

Gambar 1 Struktur geometri vitamin C sebelum optimasi

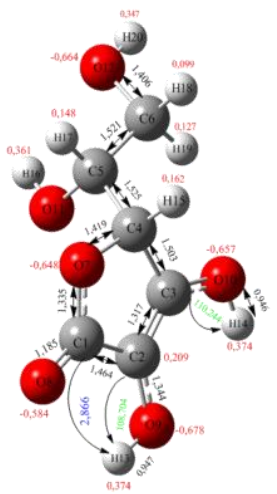

Gambar 2 Struktur geometri vitamin C sesudah optimasi

Komputasi $A b$ Initio dapat pula memperkirakan spektra IR dari molekul vitamin C. Spektra IR hasil perhitungan dapat dilihat pada gambar 3 .

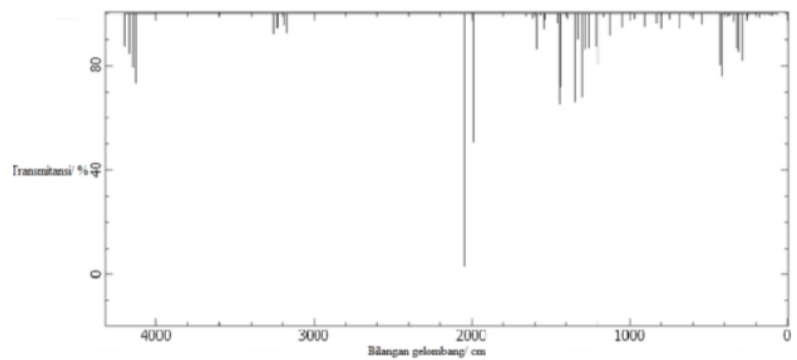

Gambar 3. Spektra IR vitamin $C$ hasil perhitungan $\mathrm{RHF} / 6-31 \mathrm{G}(\mathrm{d}, \mathrm{p})$

\section{Segmen Dimer Kitosan}

Struktur awal segmen dimer kitosan sebelum optimasi dapat dilihat pada gambar.4. Pada gambar 4 diketahui letak atom $\mathrm{O}_{29}$ dengan $\mathrm{O}_{34}$ serta $\mathrm{H}_{41}$ dengan $\mathrm{H}_{45}$ saling berdekatan, sehingga terjadi tolak menolak antar atom. Atom-atom pada segmen dimer kitosan akan terus bergerak sampai memperoleh posisi dimana efek tolakan yang dihasilkan paling kecil. Struktur segmen dimer kitosan setelah optimasi dapat dilihat pada gambar.5.

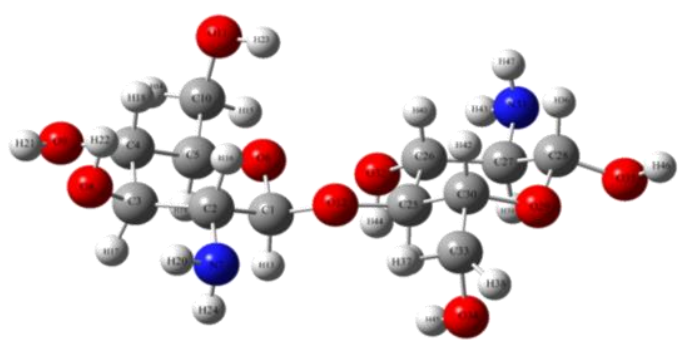

Gambar 4. Struktur geometri segmen dimer kitosan sebelum optimasi

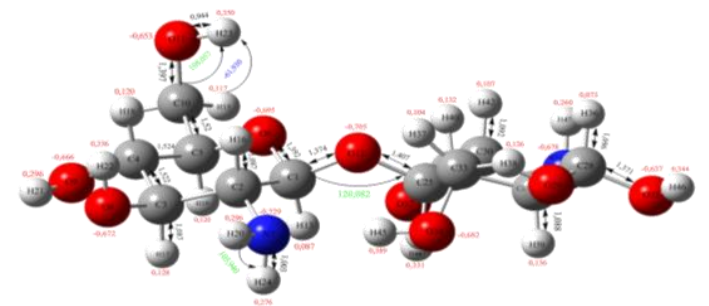

Gambar 5. Struktur geometri segmen dimer kitosan sesudah optimasi

Komputasi $A b$ Initio dapat memperkirakan spektra IR dari segmen dimer kitosan. Spektra IR dari segmen dimer kitosan dapat dilihat pada gambar 6 .

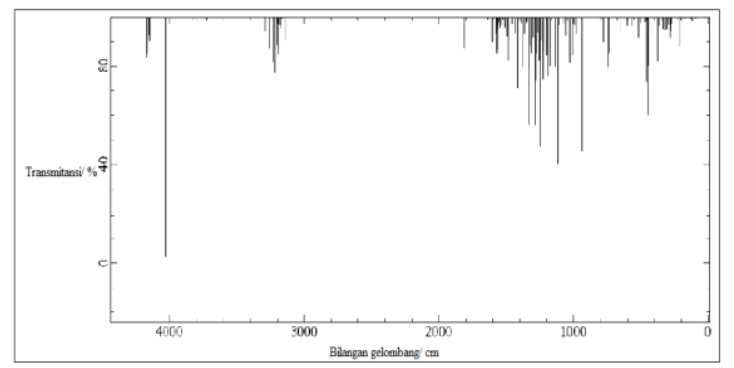

Gambar 6. Spektra IR segmen dimer kitosan hasil perhitungan RHF/6-31G(d,p)

\section{Interaksi Segmen Dimer Kitosan...Vitamin C Konfigurasi 1}

Pada optimasi interaksi geometri segmen dimer kitosan...vitamin C konfigurasi 1, dilakukan interaksi antara atom nitrogen dari segmen dimer kitosan dengan atom hidrogen dari dalam cincin vitamin C. Struktur awal optimasi interaksi geometri segmen dimer kitosan...vitamin C konfigurasi 1 dapat dilihat pada gambar 7. Atom nitrogen dapat berinteraksi dengan atom hidrogen karena atom nitrogen bermuatan negatif $0,678\left(\mathrm{~N}_{20}\right)$ sedangkan hidrogen bermuatan positif 0,374 $\left(\mathrm{H}_{48}\right)$. Struktur hasil optimasi interaksi dapat dilihat pada gambar 8 .

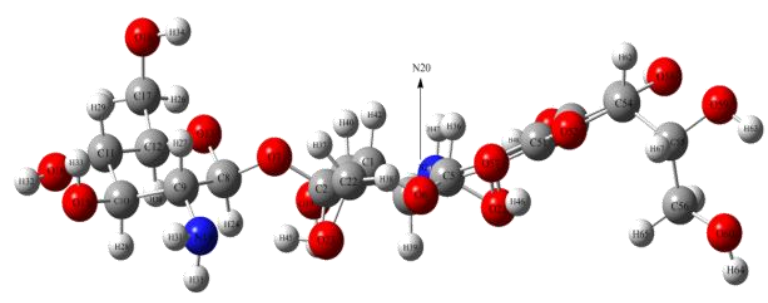

Gambar 7. Stuktur interaksi geometri segmen dimer kitosan...vitamin C konfigurasi 1 sebelum optimasi 


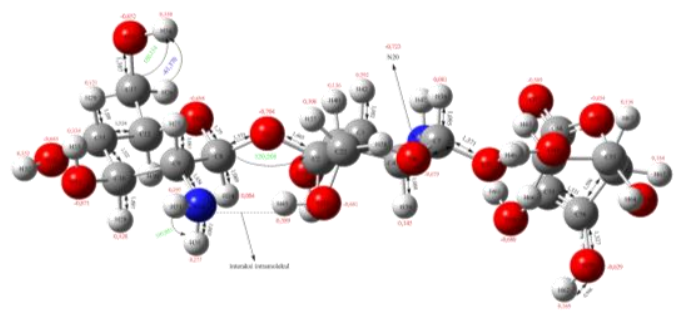

Gambar 8. Stuktur interaksi geometri segmen dimer kitosan...vitamin C konfigurasi 1 sesudah optimasi

Energi interaksi segmen dimer kitosan...vitamin C dengan variasi jarak dapat dilihat pada gambar 9. Hasil optimasi geometri menunjukkan bahwa optimasi interaksi geometri segmen dimer kitosan...vitamin $\mathrm{C}$ konfigurasi 1 mempunyai energi sebesar $-62,263 \mathrm{~kJ} \mathrm{~mol}^{-}$ ${ }^{1}$ dengan jarak interaksi 1,897 $\mathrm{A}$.

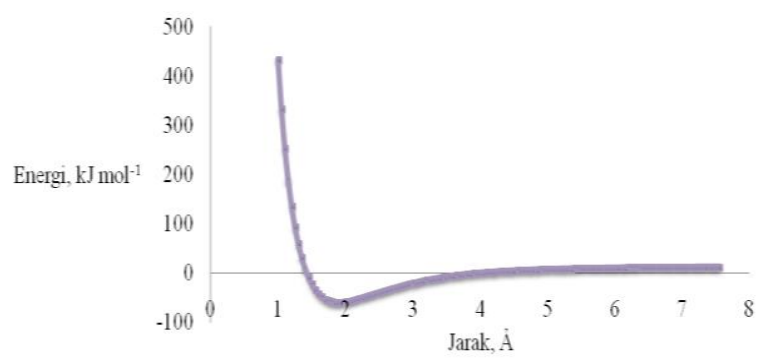

Gambar 9. Variasi jarak interaksi geometri segmen dimer kitosan...vitamin $\mathrm{C}$ konfigurasi 1, dengan $\varepsilon=-$ $62,263 \mathrm{~kJ} \mathrm{~mol}^{-1}, \mathrm{r}_{\varepsilon}=1,897 \AA$

Interaksi antar molekul segmen dimer kitosan dengan vitamin $\mathrm{C}$ menyebabkan terjadinya perubahan muatan sesudah interaksi.

Tabel 1: Perubahan jarak, sudut dan dihedral pada segmen dimer kitosan hasil interaksi segmen dimer kitosan...vitamin C konfigurasi 1

\begin{tabular}{ccccccc}
\hline \multirow{2}{*}{ Struktur } & \multicolumn{2}{c}{ Jarak } & \multicolumn{2}{c}{$\begin{array}{c}\text { Sudut } \\
\mathrm{C}_{8}-\mathrm{O}_{7}-\mathrm{C}_{2},{ }^{\circ}\end{array}$} & \multicolumn{2}{c}{$\begin{array}{c}\text { Dihedral } \\
\mathrm{C}_{8}-\mathrm{O}_{7}-\mathrm{C}_{2}-\mathrm{C}_{1},{ }^{\circ}\end{array}$} \\
\cline { 2 - 6 } & sebelum & sesudah & sebelum & sesudah & sebelum & sesudah \\
\hline $\begin{array}{c}\text { Segmen } \\
\text { dimer } \\
\text { kitosan }\end{array}$ & 1,374 & 1,377 & 120,082 & 119,552 & $-161,6$ & - \\
\hline
\end{tabular}

Tabel 2: Perubahan jarak, sudut dan dihedral pada vitamin $\mathrm{C}$ hasil interaksi segmen dimer kitosan...vitamin C konfigurasi 1

\begin{tabular}{ccccccc}
\hline \multirow{2}{*}{ Struktur } & \multicolumn{2}{c}{$\begin{array}{c}\text { Jarak } \\
\mathrm{H}_{48}-\mathrm{O}_{49}, \AA\end{array}$} & \multicolumn{2}{c}{$\begin{array}{c}\text { Sudut } \\
\mathrm{H}_{48}-\mathrm{O}_{49}-\mathrm{C}_{50},{ }^{\circ}\end{array}$} & \multicolumn{2}{c}{$\begin{array}{c}\text { Dihedral } \\
\mathrm{H}_{48}-\mathrm{O}_{49}-\mathrm{C}_{50}-\mathrm{C}_{51},{ }^{\circ}\end{array}$} \\
\cline { 2 - 7 } & Sebelum & Sesudah & Sebelum & Sesudah & Sebelum & Sesudah \\
\hline $\begin{array}{c}\text { Vitamin } \\
\mathrm{C}\end{array}$ & 0,947 & 0,964 & 108,704 & 112,732 & 2,866 & 38,968 \\
\hline
\end{tabular}

Tabel 3: Perubahan muatan atom-atom yang berinteraksi hasil interaksi segmen dimer kitosan...vitamin C konfigurasi 1

\begin{tabular}{cccc}
\hline \multicolumn{2}{c}{ Atom $\mathrm{N}_{20}$} & \multicolumn{2}{c}{ Atom $\mathrm{H}_{48}$} \\
\hline sebelum & sesudah & sebelum & sesudah \\
\hline$-0,678$ & $-0,766$ & 0,374 & 0,431 \\
\hline
\end{tabular}

Komputasi $A b$ Initio dapat pula memperkirakan spektra IR dari segmen dimer kitosan...vitamin C konfigurasi 1. Spektra IR hasil interaksi dapat dilihat pada gambar 10.

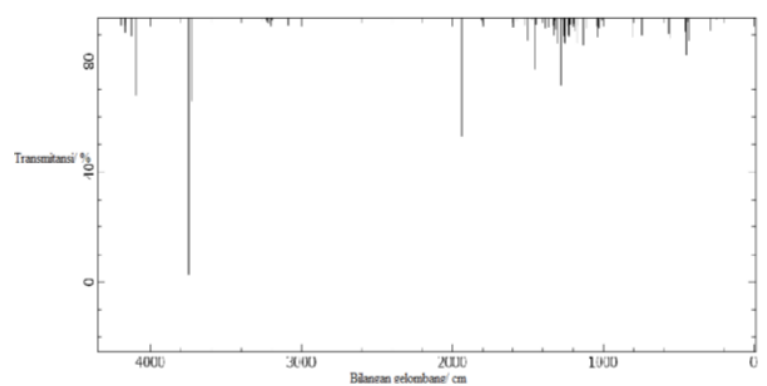

Gambar 10. Spektra IR segmen dimer kitosan...vitamin C konfigurasi 1 hasil perhitungan $\mathrm{RHF} / 6-31 \mathrm{G}(\mathrm{d}, \mathrm{p})$

Interaksi Segmen Dimer Kitosan...Vitamin C Konfigurasi 2.

Pada optimasi interaksi geometri segmen dimer kitosan...vitamin C konfigurasi 2 dilakukan interaksi antara atom hidrogen dari luar cincin vitamin $\mathrm{C}$ dengan atom nitrogen dari segmen dimer kitosan. Pemilihan interaksi ini dikarenakan atom $\mathrm{H}_{20}$ dari vitamin $\mathrm{C}$ memiliki muatan positif terbesar kedua yakni 0,347 . Hasil optimasi geometri interaksi segmen dimer kitosan...vitamin C konfigurasi 2 sebelum berinteraki dapat dilihat pada gambar 11 sedangkan setelah berinteraksi pada gambar 12 .

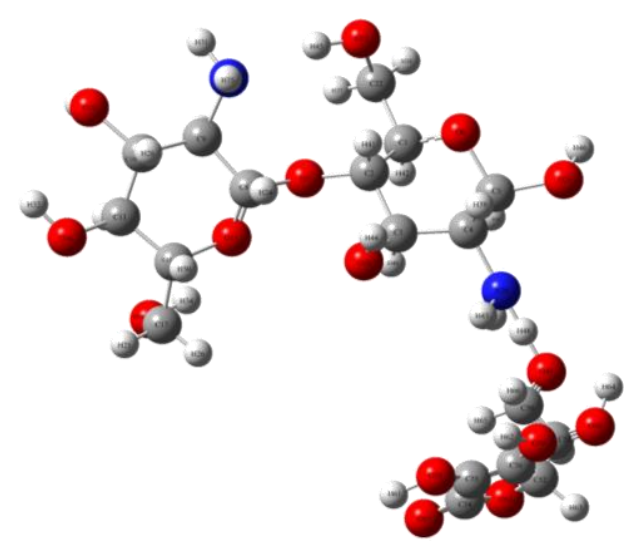

Gambar 11 Stuktur optimasi interaksi geometri segmen dimer kitosan...vitamin C konfigurasi 2 sebelum optimasi

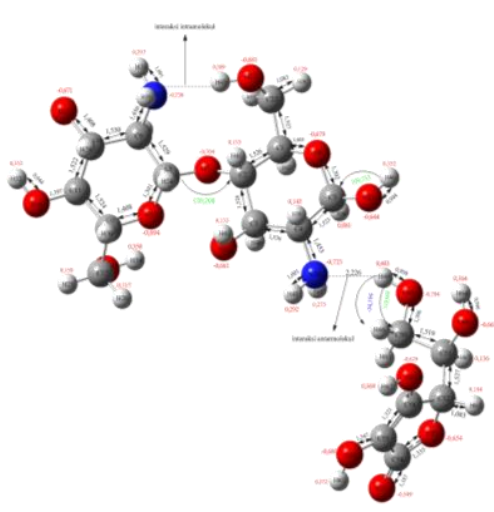

Gambar 12. Stuktur optimasi interaksi geometri segmen dimer kitosan...vitamin C konfigurasi 2 setelah optimasi 
Energi interaksi segmen dimer kitosan...vitamin C sebagai fungsi jarak dapat dilihat pada gambar IV.14. Hasil optimasi geometri menunjukan bahwa optimasi interaksi geometri segmen dimer kitosan...vitamin C konfigurasi 2 mempunyai energi sebesar $-32,641 \mathrm{~kJ} \mathrm{~mol}^{-}$ ${ }^{1}$ dengan jarak interaksi 2,226 $\AA$.

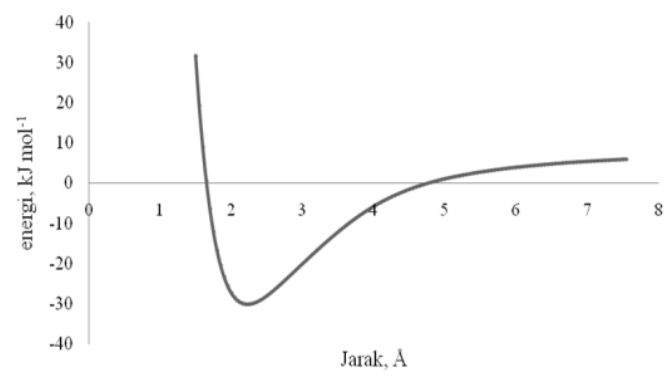

Gambar 13 Variasi jarak interaksi geometri segmen dimer kitosan...vitamin C konfigurasi 2, dengan $\varepsilon=-$ $32,641 \mathrm{~kJ} \mathrm{~mol}^{-1}, \mathrm{r}_{\varepsilon}=2,226 \AA$

Interaksi antar molekul segmen dimer kitosan dengan vitamin $\mathrm{C}$ menyebabkan terjadinya perubahan muatan sesudah interaksi

Tabel 4: Perubahan jarak, sudut dan dihedral pada segmen dimer kitosan hasil interaksi segmen dimer kitosan...vitamin C konfigurasi 2

\begin{tabular}{ccccccc}
\hline \multirow{2}{*}{ Struktur } & \multicolumn{2}{c}{$\begin{array}{c}\text { Jarak } \\
\mathrm{C}_{8}-\mathrm{O}_{7}, \AA\end{array}$} & \multicolumn{2}{c}{$\begin{array}{c}\text { Sudut } \\
\mathrm{C}_{8}-\mathrm{O}_{7}-\mathrm{C}_{2},{ }^{\circ}\end{array}$} & \multicolumn{2}{c}{$\begin{array}{c}\text { Dihedral } \\
\mathrm{C}_{8}-\mathrm{O}_{7}-\mathrm{C}_{2}-\mathrm{C}_{1},{ }^{\circ}\end{array}$} \\
\cline { 2 - 7 } & sebelum & sesudah & sebelum & sesudah & sebelum & sesudah \\
\hline $\begin{array}{c}\text { Segmen } \\
\text { dimer } \\
\text { kitosan }\end{array}$ & 1,374 & 1,375 & 120,082 & 120,208 & $-161,600$ & $-161,186$ \\
\hline
\end{tabular}

Tabel 5: Perubahan jarak, sudut dan dihedral pada vitamin $\mathrm{C}$ hasil interaksi segmen dimer kitosan...vitamin C konfigurasi 2

\begin{tabular}{ccccccc}
\hline \multirow{2}{*}{ Struktur } & \multicolumn{2}{c}{$\begin{array}{c}\text { Jarak } \\
\mathrm{H}_{48}-\mathrm{O}_{49}, \AA\end{array}$} & \multicolumn{2}{c}{$\begin{array}{c}\text { Sudut } \\
\mathrm{H}_{48}-\mathrm{O}_{49}-\mathrm{C}_{50},{ }^{\circ}\end{array}$} & \multicolumn{2}{c}{$\begin{array}{c}\text { Dihedral } \\
\mathrm{H}_{48}-\mathrm{O}_{49}-\mathrm{C}_{50}-\mathrm{C}_{51},{ }^{\circ}\end{array}$} \\
\cline { 2 - 7 } & sebelum & sesudah & sebelum & sesudah & sebelum & sesudah \\
\hline $\begin{array}{c}\text { vitamin } \\
\mathrm{C}\end{array}$ & 0,942 & 0,950 & 110,411 & 110,048 & $-169,778$ & $-173,126^{\circ}$ \\
\hline
\end{tabular}

Tabel 6: Perubahan muatan atom-atom yang berinteraksi hasil interaksi segmen dimer kitosan...vitamin C konfigurasi 2

\begin{tabular}{cccc}
\hline \multicolumn{2}{c}{ Atom $\mathrm{N}_{20}$} & \multicolumn{2}{c}{ Atom $\mathrm{H}_{48}$} \\
\hline sebelum & sesudah & sebelum & sesudah \\
\hline$-0,678$ & $-0,723$ & 0,374 & 0,403 \\
\hline
\end{tabular}

Interaksi antara segmen dimer kitosan...vitamin C konfigurasi 2 memiliki energi interaksi cukup negatif yakni sebesar $-32,641 \mathrm{~kJ} \mathrm{~mol}^{-1}$, namun nilai tersebut kurang negatif jika dibandingkan dengan konfigurasi 1 yang bernilai $-62,263 \mathrm{~kJ} \mathrm{~mol}^{-1}$. Energi interaksi segmen dimer kitosan dengan vitamin $\mathrm{C}$ konfigurasi 1 bernilai lebih besar dari pada konfigurasi 2 sehingga konfigurasi 1 lebih disukai (stabil) dibandingkan konfigurasi 2.

Komputasi $A b$ Initio dapat pula memperkirakan spektra IR dari segmen dimer kitosan...vitamin C konfigurasi 2. Spektra IR dari segmen dimer kitosan...vitamin C konfigurasi 2 dapat dilihat pada gambar 14 .

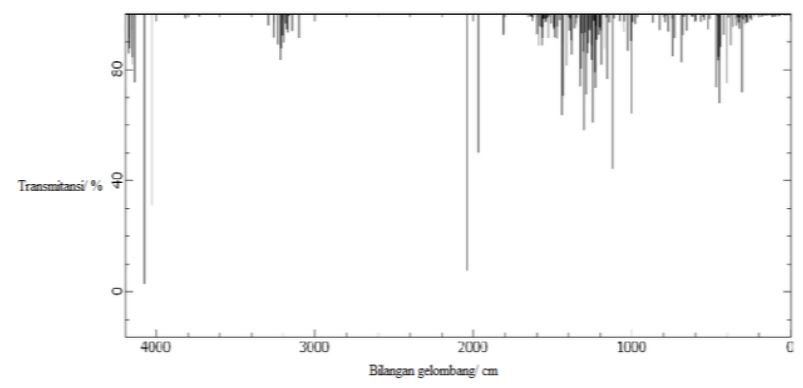

Gambar 14. Spektra IR segmen dimer kitosan...vitamin C konfigurasi 2 hasil perhitungan $\mathrm{RHF} / 6-31 \mathrm{G}(\mathrm{d}, \mathrm{p})$

Hasil perhitungan komputasi $a b$ initio diketahui bahwa energi interaksi antara segmen dimer kitosan...vitamin C tergantung dari atom-atom yang berinteraksi. Interaksi antara segmen dimer kitosan...vitamin C konfigurasi 1 menghasilkan energi interaksi yang lebih besar (lebih stabil) dibandingkan dengan konfigurasi 2. Adanya perbedaan energi interaksi ini diperkirakan menyebabkan vitamin C dapat lepas secara perlahan-lahan jika ada molekul lain yang interaksikan, seperti $\mathrm{H}_{2} \mathrm{O}$.

\section{Adsorpsi Vitamin C dalam Kitosan}

Pada penelitian ini digunakan 2,5 gram kitosan dengan vitamin $\mathrm{C}$ 0,25\%. Pemasukan vitamin $\mathrm{C}$ dalam kitosan dilakukan dengan cara perendaman selama 120 menit disertai pengadukan. Spektra kitosan yang sudah mengandung vitamin $\mathrm{C}$ dapat dilihat pada gambar 15 .

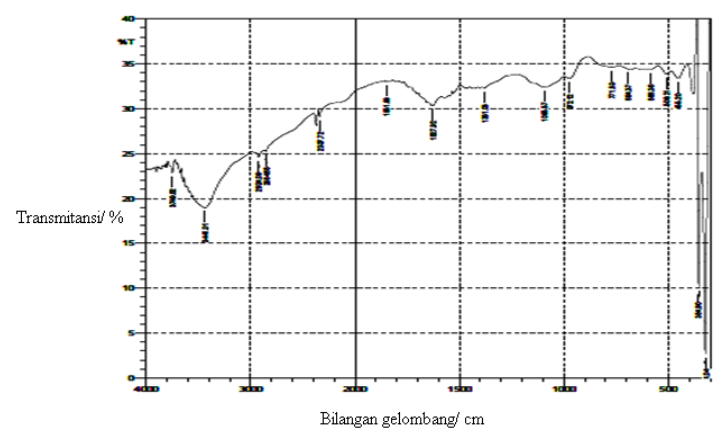

Gambar 15. Spektra kitosan...vitamin C hasil eksperimen

Spektra FTIR kitosan...vitamin C hasil eksperimen, tidak sesuai dengan hasil perhitungan komputasi. Hal ini disebabkan pada perhitungan komputasi hanya dihitung segmen dimer kitosan dengan molekul tunggal vitamin $\mathrm{C}$ saja sehingga tidak ada pengaruh dari vitamin $\mathrm{C}$ maupun kitosan lainnya. Disamping itu perhitungan komputasi di asumsikan bahwa segmen dimer kitosan...vitamin $\mathrm{C}$ berada pada fase gas, sehingga tidak ada pengaruh dari pelarut.

Sisa larutan vitamin $\mathrm{C}$ setelah adsorpsi kemudian diukur dengan spektrofotometer UV-Vis pada panjang gelombang $265 \mathrm{~nm}$. Pengukuran ini bertujuan untuk mengetahui konsentrasi vitamin $\mathrm{C}$ yang terserap dalam kitosan. Berdasarkan hasil pengukuran diketahui bahwa vitamin $\mathrm{C}$ yang terserap dalam kitosan sebesar 1.028 ppm atau 45,6\%. 


\section{Uji Lepas Lambat Vitamin C}

Vitamin C yang terserap dalam kitosan kemudian di uji kemampuan desorpsi dengan memasukan dalam media air dan disertai pengadukan. Konsentrasi vitamin C yang dilepas oleh kitosan kemudian diuji setiap sepuluh menit sekali. Hasil pengujian dapat dilihat pada gambar 16. Hasil eksperimen menunjukan bahwa tidak semua vitamin $\mathrm{C}$ yang terserap dalam kitosan dapat lepas dalam media air. Hal ini disebabkan terjadinya kompetisi interaksi antara segmen dimer kitosan...vitamin C dengan vitamin C...air. Disamping itu kemampuan vitamin $\mathrm{C}$ untuk lepas secara bertahap dari kitosan disebabkan karena adanya perbedaan energi interaksi antara segmen dimer kitosan...vitamin C. Energi interaksi yang lebih besar akan terlepas terlebih dahulu dalam media air dan di ikuti dengan energi interaksi yang lebih rendah.

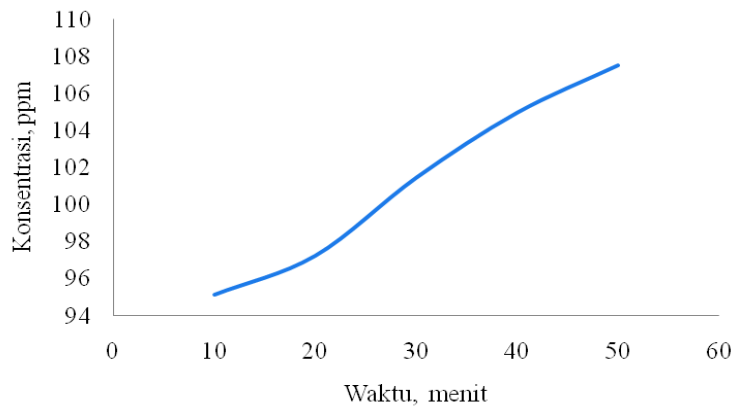

Gambar 16. Hubungan konsentrasi vitamin C dengan waktu pelepasan dalam media air

Dari gambar 16 diketahui pelepasan vitamin C pada 10 menit pertama cukup besar yakni 95,15 ppm namun pelepasan konsentrasi untuk 10 menit berikutnya mengalami penurunan. Konsentrasi vitamin $\mathrm{C}$ yang pertama kali dilepas sebanding dengan konsentrasi awal vitamin $\mathrm{C}$ yang dibutuhkan oleh tubuh namun pada pelepasan berikutnya mengalami penurunan pelepasan, sehingga termasuk mekanisme pelepasan sustained release. Vitamin $\mathrm{C}$ yang tekandung dalam kitosan tetap lepas secara perahan-lahan sampai 24 jam kemudian. Diharapkan pelepasan vitamin C secara perlahan-lahan ini terus berlangsung sampai semua vitamin $\mathrm{C}$ yang terkandung dalam kitosan terlepas semua.

\section{Kesimpulan}

Segmen dimer kitosan dapat berinteraksi dengan vitamin $\mathrm{C}$ yang besar energi interaksi setiap konfigurasi tergantung dari atom-atom yang berinteraksi. Energi interaksi antara segmen dimer kitosan...vitamin C konfigurasi 1 sebesar $-62,263 \mathrm{~kJ} \mathrm{~mol}^{-1}$ dengan jarak $1,897 \AA$ sedangkan untuk konfigurasi 2 sebesar -32,641

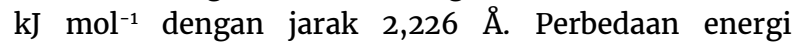
interaksi tersebut disebabkan oleh muatan, jarak ikatan, sudut ikatan dan dihedral. Adanya interaksi antara segmen dimer kitosan...vitamin $\mathrm{C}$ diperkirakan kitosan dapat digunakan untuk menyerap vitamin $\mathrm{C}$ selain itu adanya perbedaan energi interaksi diperkirakan terjadinya pelepasan vitamin C secara bertahap. Berdasarkan hasil eksperimen, kitosan dapat mengadsorpsi vitamin C sebesar $46,5 \%$ dan kemampuan vitamin C untuk lepas dari kitosan pada 10 menit awal sebesar 95,15 ppm.

\section{Daftar Pustaka}

[1] S. Roller, N. Covill, The antifungal properties of chitosan in laboratory media and apple juice, International Journal of Food Microbiology, 47, 1, (1999) 67-77 http://dx.doi.org/10.1016/S01681605(99)00006-9

[2] Pradip Kumar Dutta, Joydeep Dutta, VS Tripathi, Chitin and chitosan: Chemistry, properties and applications, (2004)

[3] B Chutichudet, Prasit Chutichudet, Effects of chitosan coating to some postharvest characteristics of Hylocercus undatus (Haw) Britton and Rose fruit, International Journal of Agricultural Research, 6, 1, (2011)

82-92 http://dx.doi.org/10.3923/ijar.2011.82.92

[4] Masayuki Ishihara, Kiyohaya Obara, Singo Nakamura, Masanori Fujita, Kazunori Masuoka, Yasuhiro Kanatani, Bonpei Takase, Hidemi Hattori, Yuji Morimoto, Miya Ishihara, Tadaaki Maehara, Makoto Kikuchi, Chitosan hydrogel as a drug delivery carrier to control angiogenesis, Journal of Artificial Organs, 9, 1, (2006) 8-16 http://dx.doi.org/10.1007/s10047-005-0313-0

[5] Muflikhah, Perhitungan AB Initio Interaksi Antara Trikalsium Fosfat Dan Hidroksiapatit Dengan Segmen Molekul Selulosa, Kimia, Universitas Diponegoro, Semarang 